\title{
Accumulation in East Greenland Fjords and on the Continental Shelves Adjacent to the Denmark Strait over the Last Century Based on ${ }^{210} \mathrm{~Pb}$ Geochronology
}

\author{
L. MICAELA SMITH, ${ }^{1,2}$ CLARK ALEXANDER ${ }^{3}$ and ANNE E. JENNINGS ${ }^{1}$
}

(Received 10 October 2000; accepted in revised form 24 July 2001)

\begin{abstract}
Sediment (SAR) and mass (MAR) accumulation rates for the last 100 years are derived from ${ }^{210} \mathrm{~Pb}$ profiles of box cores collected in three fjords and on the continental shelf in the Kangerlussuaq region, East Greenland, and on the SW Iceland continental shelf. The MAR is lower on East Greenland $\left(0.09 \mathrm{~g} / \mathrm{cm}^{2} \cdot \mathrm{yr}\right)$ than on SW Iceland $\left(0.14 \mathrm{~g} / \mathrm{cm}^{2} \cdot \mathrm{yr}\right)$ because of differences in the biogenic component of the sediments, although SAR is similar. The differences in accumulation rates of the three East Greenland fjords are due to their dominant sediment sources and basin areas. Kangerlussuaq Fjord, the largest fjord, is dominated by iceberg sediment input and has a MAR of $0.43 \mathrm{~g} / \mathrm{cm}^{2} \cdot \mathrm{yr}$ at $50 \mathrm{~km}$ from the fjord head. Miki Fjord, the smallest fjord, is dominated by glaciofluvial sediment input with a MAR of $0.29 \mathrm{~g} / \mathrm{cm}^{2} \cdot \mathrm{yr}$ of sediment at $10 \mathrm{~km}$ from the fjord head. Nansen Fjord is intermediate in size, with an iceberg-dominated sediment supply; MAR is $1.01 \mathrm{~g} / \mathrm{cm}^{2} \cdot \mathrm{yr}$ near the fjord head and $0.17 \mathrm{~g} / \mathrm{cm}^{2} \cdot \mathrm{yr}$ at $20 \mathrm{~km}$ from the fjord head. ${ }^{137} \mathrm{Cs}$ is used as a secondary indicator of sediment source, and the high activity level of ${ }^{137} \mathrm{Cs}$ in Miki Fjord indicates glaciofluvial sediment sources. Zones of constant activity in some of the box cores are attributed to either bioturbation in the surface mixed layer or turbidites. We would be hesitant to extend the recent ${ }^{210} \mathrm{~Pb}$-based accumulation rates to estimate the Holocene accumulation rates.
\end{abstract}

Key words: mass accumulation, sediment accumulation, lead-210, cesium-137, Greenland, Iceland, fjords

RÉSUMÉ. On a calculé les taux d'accumulation de sédiments (TAS) et de masse (TAM) pour les cent dernières années à partir des profils $\mathrm{du}{ }^{210} \mathrm{~Pb}$ dans des carottes rectangulaires prélevées dans trois fjords et sur le plateau continental de la région de Kangerlussuaq (est du Groenland), et sur le plateau continental du sud-ouest de l'Islande. Le TAM est plus faible dans l'est du Groenland $\left(0,09 \mathrm{~g} / \mathrm{cm}^{2}\right.$ par an $)$ que dans le sud-ouest de l'Islande $\left(0,14 \mathrm{~g} / \mathrm{cm}^{2}\right.$ par an) en raison des différences dans la composante biogène des sédiments, bien que le TAS soit similaire. La différence entre les taux d'accumulation des trois fjords de l'est du Groenland est due à leurs sources majeures de sédiments et à leurs bassins de réception. Le fjord Kangerlussuaq, le plus grand des trois, est dominé par un apport de sédiments provenant d'icebergs et a un TAM de $0,43 \mathrm{~g} / \mathrm{cm}^{2}$ par an à $50 \mathrm{~km}$ de son extrémité amont. Le fjord Miki, qui est le plus petit, est dominé par un apport de sédiments fluvio-glaciaires avec un TAM de $0,29 \mathrm{~g} / \mathrm{cm}^{2}$ par an de sédiments à $10 \mathrm{~km}$ de son extrémité amont. Le fjord Nansen est de taille moyenne, et l'apport sédimentaire y provient en majorité d'icebergs; le TAM est de $1,01 \mathrm{~g} / \mathrm{cm}^{2}$ par an près de l'extrémité amont et de $0,17 \mathrm{~g} / \mathrm{cm}^{2}$ par an à $20 \mathrm{~km}$ de l'extrémité amont. Le ${ }^{137} \mathrm{Cs}$ est utilisé comme indicateur secondaire de la source de sédiments, et le niveau d'activité élevé du ${ }^{137} \mathrm{Cs}$ dans le fjord Miki révèle que les sédiments sont d'origine fluvio-glaciaire. Dans certaines des carottes rectangulaires, on attribue les zones d'activité constante soit à une bioturbation dans la couche mixte de surface, soit à des turbidités. Nous hésiterions à recourir aux récents taux d'accumulation fondés sur $1 \mathrm{l}^{210} \mathrm{~Pb}$ pour estimer les taux d'accumulation durant l'holocène.

Mots clés: accumulation de masse, accumulation de sédiments, plomb 210, césium 137, Groenland, Islande, fjords

Traduit pour la revue Arctic par Nésida Loyer.

\section{INTRODUCTION}

High-resolution terrestrial, ice-core, and marine records have shown that the Holocene climate and ocean environments are not stable, but are instead influenced by decadal to century-scale variability, especially in the Arctic (Dickson et al., 1988; Jennings and Weiner, 1996; Andrews et al., 1997; Overpeck et al., 1997). Additionally, although the Arctic may be one of the least populated regions of the world, it may be highly susceptible to anthropogenically induced climate warming (Overpeck et al., 1997). Hence, studies of Arctic records of the recent past provide information on both natural and humaninduced climate variability.

In order to best interpret paleoenvironmental records, we need to calibrate the last 100 years of the record to the historical record. Yet, the calibration hinges on establishing a reliable chronology for the last 100 years of the

\footnotetext{
${ }^{1}$ Department of Geological Sciences and Institute of Arctic and Alpine Research, University of Colorado, Campus Box 450, Boulder, Colorado 80309-0450, U.S.A

${ }^{2}$ Present address: BP Exploration (Alaska), Inc., 900 E. Benson Blvd., Anchorage, Alaska 99519, U.S.A.; laryn.smith@bp.com

${ }^{3}$ Skidaway Institute of Oceanography, 10 Ocean Science Circle, Savannah, Georgia 31411, U.S.A.

(C) The Arctic Institute of North America
} 
paleoenvironmental record. Radiocarbon dating is the chronological tool most frequently used in paleoenvironmental studies, but the fluctuating $\Delta{ }^{14} \mathrm{C}$ of the atmosphere over the last 1000 years makes it difficult to develop reliable chronologies for the most recent past (Stuiver, 1993; Stuiver and Pearson, 1993). ${ }^{210} \mathrm{~Pb}$ is a better tool for developing sediment and mass accumulation rates for sediments deposited during the last 150 years (Appleby and Oldfield, 1992). Yet, ${ }^{210} \mathrm{~Pb}$ is not a geochronological tool suitable for every glacial marine environment (Harden et al., 1992; Jaeger and Nittrouer, 1999), and its usefulness must be evaluated for the marine setting under study.

To investigate the feasibility of constructing reliable chronologies for the last 100 years on the continental shelves adjacent to the Denmark Strait, we applied ${ }^{210} \mathrm{~Pb}$ geochronology methods to six box cores that recovered the most recently deposited sediments from the East Greenland shelf and fjords and the SW Iceland shelf. The box cores were collected from different environmental settings, from the iceberg-dominated glacial marine environment of East Greenland to the hemipelagic marine environment of the SW Iceland continental shelf (Fig. 1, Table 1). Sediment and mass accumulation rates are estimated from the ${ }^{210} \mathrm{~Pb}$ data and used to evaluate paleoenvironmental changes in the study region over the last century. This study has three objectives: (1) to develop ${ }^{210} \mathrm{~Pb}$-based accumulation rates for the fjords and continental shelves bordering the Denmark Strait; (2) to compare ${ }^{210} \mathrm{~Pb}$-based accumulation rates of the two high-latitude continental shelves and the three contrasting fjords in the context of local sedimentary processes; and (3) to document any changes in sedimentation-related processes in this region over the last century.

\section{BACKGROUND}

\section{Physical Setting}

The fjords and continental shelves of East Greenland and West Iceland (Fig. 1) are a result of modification by tectonic, climatic, marine, and glaciological processes. Presently, East Greenland remains heavily glaciated (Dwyer, 1995) and is cooled by the cold, southwardflowing East Greenland Current. Marine sediments deposited within the Kangerlussuaq Trough on the East Greenland shelf are rich in biogenic silica and contain a small component of iceberg-rafted detritus (Clapsaddle, 1994; Williams et al., 1995; Andersen, 1998). In contrast, southwest Iceland is predominantly ice-free and is warmed by the warm, northward-flowing Irminger Current. The SW Iceland marine sediments are characterized by tephra grains in the sand fraction and biogenic carbonate and fecal pellets (Jennings et al., 2000).

Three East Greenland fjords were investigated: Kangerlussuaq, Miki, and Nansen. Kangerlussuaq Fjord is the largest and deepest of the three fjords (Fig. 1). The main tidewater glacier at the head drains the Greenland Ice Sheet and maintains a sikkusaq, a mélange of sea ice and icebergs at the tidewater terminus (Dwyer, 1995). Approximately $15 \mathrm{~km}^{3}$ of ice is calved into the sikkusaq each year (Reeh, 1985), and these icebergs take up to two years to transit through the sikkusaq (Dwyer, 1995; Syvitski et al., 1996). Miki Fjord is sinuous, narrow, and shallow (Fig. 1). There is a proglacial outwash delta at the fjord head formed by meltwater streams emanating from the Sødalen Gletscher, which lies $5 \mathrm{~km}$ away in the hinterland (Geirsdóttir et al., 2000). Nansen Fjord is wide and short, and it is partially silled along the southwest (Fig. 1). Christian IV Gletscher,

TABLE $1 .{ }^{210} \mathrm{~Pb}$ SAR and MAR rates for the six sediment cores from the East Greenland fjords and the East Greenland and southwest Iceland continental shelves used in this study (above), and radiocarbon dates for one of those (96-1212) and three other sediment cores (below). (Core 93-28 is from Syvitski et al., 1996; 91-K10 and 91-K14 are from Smith and Andrews, 2000.)

\begin{tabular}{|c|c|c|c|c|c|c|c|c|c|c|c|c|c|c|}
\hline Core & $\begin{array}{l}\text { Core } \\
\text { type }^{1}\end{array}$ & $\begin{array}{l}\text { Latitude } \\
\text { (N) }\end{array}$ & $\begin{array}{l}\text { Longitude } \\
\text { (W) }\end{array}$ & $\begin{array}{c}\text { Water } \\
\text { Depth } \\
(\mathrm{m})\end{array}$ & $\begin{array}{l}\text { Core } \\
\text { Length } \\
(\mathrm{cm})\end{array}$ & $\begin{array}{c}{ }^{14} \mathrm{C} \text { sample } \\
\text { depth } \\
(\mathrm{cm})\end{array}$ & Lab \# & $\begin{array}{l}\text { Rep. } \\
\text { Age }\end{array}$ & $\begin{array}{l}\text { Error } \\
\text { (yrs) }\end{array}$ & $\begin{array}{l}\text { Cal age } \\
\text { (cal yrs) }\end{array}$ & $\begin{array}{l}\text { One } \sigma \\
\text { range } \\
\text { (cal yrs) }\end{array}$ & $\begin{array}{c}{ }^{10} \mathrm{~Pb} \\
\text { method }\end{array}$ & $\begin{array}{l}{ }^{210} \mathrm{~Pb} \\
\mathrm{MAR}\end{array}$ & $\begin{array}{l}{ }^{210} \mathrm{~Pb} \\
\mathrm{SAR}\end{array}$ \\
\hline $93-3$ & $\mathrm{BC}$ & $64^{\circ} 18.00$ & $24^{\circ} 13.9$ & 250 & 55 & & & & & & & alpha & 0.14 & 0.22 \\
\hline $93-19$ & $\mathrm{BC}$ & $67^{\circ} 08.73$ & $30^{\circ} 49.34$ & 713 & 60 & & & & & & & alpha & 0.09 & 0.20 \\
\hline $93-23$ & $\mathrm{BC}$ & $68^{\circ} 08.19$ & $31^{\circ} 52.62$ & 878 & 54 & & & & & & & alpha & 0.43 & 0.42 \\
\hline $96-1212$ & $\mathrm{LBC}$ & $68^{\circ} 09.8$ & $31^{\circ} 21.6$ & 30 & 45 & & & & & & & gamma & 0.25 & 0.3 \\
\hline $96-1209$ & $\mathrm{LBC}$ & $68^{\circ} 17.8$ & $29^{\circ} 47.9$ & 320 & 60 & & & & & & & gamma & 1.01 & 1.36 \\
\hline $96-1210$ & SBC & $68^{\circ} 11.00$ & $29^{\circ} 36.00$ & 452 & 25 & & & & & & & gamma & 0.17 & 0.22 \\
\hline $93-28^{2}$ & $\mathrm{LCF}$ & $68^{\circ} 08.05$ & $31^{\circ} 52.08$ & 874 & 1560 & 1560 & CAM-13044 & 1430 & 60 & 806 & $906-721$ & & & \\
\hline $96-1212^{2}$ & GC & $68^{\circ} 09.8$ & $31^{\circ} 21.6$ & 30 & 100 & 20 & AA-27762 & 5 & 40 & modern & $\mathrm{n} / \mathrm{a}$ & & & \\
\hline \multirow[t]{2}{*}{$91-\mathrm{K} 10^{2}$} & GC & $68^{\circ} 09.51$ & $31^{\circ} 23.70$ & 199 & 122 & $0-10$ & AA-8959 & 10530 & 135 & $\mathrm{n} / \mathrm{a}$ & $\mathrm{n} / \mathrm{a}$ & & & \\
\hline & & & & & & $194-199$ & AA-8960 & 12220 & 130 & $\mathrm{n} / \mathrm{a}$ & $\mathrm{n} / \mathrm{a}$ & & & \\
\hline \multirow[t]{3}{*}{$91-\mathrm{K} 14^{2}$} & GC & $68^{\circ} 11.49$ & $29^{\circ} 35.74$ & 459 & 162 & $49-51$ & AA-12891 & 855 & 60 & 313 & $431-270$ & & & \\
\hline & & & & & & $114-117$ & AA-10567 & 1440 & 70 & 827 & $916-723$ & & & \\
\hline & & & & & & $>170$ & AA-8332 & 1798 & 111 & 1202 & $1295-1059$ & & & \\
\hline
\end{tabular}

\footnotetext{
${ }^{1} \mathrm{BC}=$ box core, $\mathrm{LBC}=$ large box core, $\mathrm{SBC}=$ short box core, $\mathrm{LCF}=$ long core facility, and GC = gravity core.

${ }^{2}{ }^{14} \mathrm{C}$ date references - 93-28 and 96-1212: Smith and Licht, 2000; 91-K10: Manley and Jennings, 1996; 91-K14: Jennings and Weiner, 1996.
} 


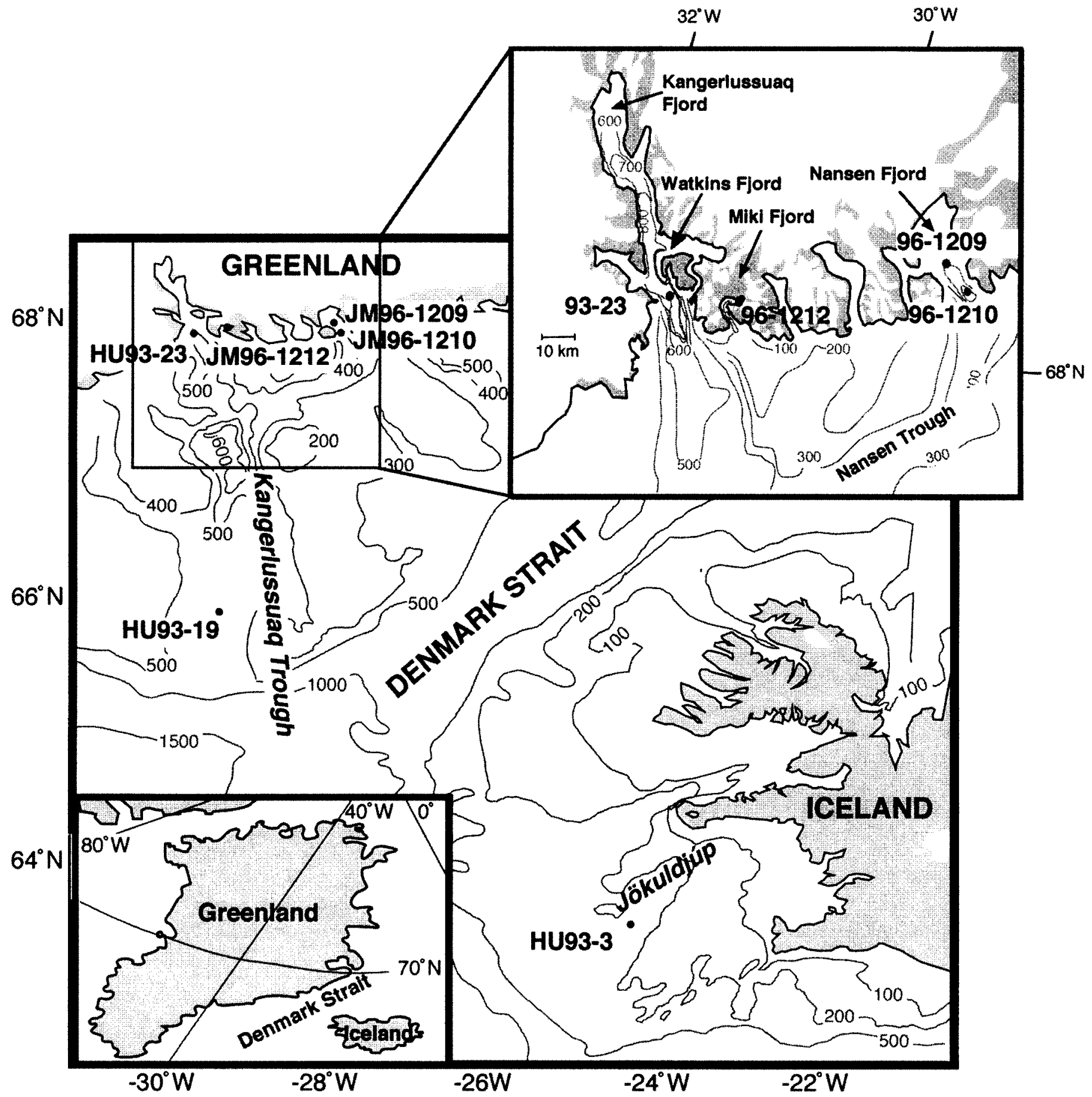

FIG. 1. Location map showing bathymetry (m), core locations, and ice cover extent (white areas on land) in the fjords and the inner continental shelf of the Kangerlussuaq region, East Greenland, and southwest Iceland.

at the fjord head, drains a local ice cap and calves an estimated $2 \mathrm{~km}^{3}$ of icebergs per year (Andrews et al., 1994). The sediment input of the East Greenland fjords is dominated by rain-out processes from glacial marine sources, including tidewater-glacier margins, proglacial rivers, or iceberg-rafted debris, with secondary depositional processes of gravity flows, either turbidites or debris flows (Andrews et al., 1994; Jennings and Weiner, 1996; Syvitski et al., 1996; Smith and Andrews, 2000).

\section{Previous Research}

Previously published estimates of sediment accumulation rates (SAR) in the fjords and continental shelves of East Greenland and SW Iceland (Table 2) were based on radiocarbon dating of foraminifera and molluses (Andrews et al., 1994, 1996; Jennings and Weiner, 1996; Syvitski et al., 1996; Jennings et al., 2000, 2001). There is one study of the modern-day SAR and mass accumulation 
TABLE 2. Comparison of estimates of sediment accumulation rates based on ${ }^{210} \mathrm{~Pb},{ }^{14} \mathrm{C}$, and modern observational data.

\begin{tabular}{|c|c|c|c|c|c|}
\hline Location & Core & ${ }^{210} \mathrm{~Pb}$ estimate $(\mathrm{cm} / \mathrm{yr})$ & ${ }^{14} \mathrm{C}$ estimate $(\mathrm{cm} / \mathrm{yr})$ & Modern (cm/yr) & ${ }^{14} \mathrm{C}$ estimate reference \\
\hline SW Iceland Shelf & HU93-3 & 0.22 & 0.002 & & Jennings et al., 2001 \\
\hline Kangerlussuaq Trough & HU93-19 & 0.20 & 0.006 & & Andrews et al., 1996 \\
\hline Kangerlussuaq Fjord & HU93-23 & 0.42 & $2.15 / 0.83^{1}$ & $0.9^{2}$ & Smith, 1997 \\
\hline Miki Fjord & JM96-1212 & 0.31 & 0.12 & & Smith, 1997 \\
\hline Nansen Fjord (inner) & JM96-1209 & 1.36 & 0.18 & & Smith, 1997 \\
\hline Nansen Fjord (outer) & JM96-1210 & 0.22 & 0.13 & & Jennings and Weiner, 1996 \\
\hline
\end{tabular}

${ }^{1} 2.15 \mathrm{~cm} / \mathrm{yr}$ is the accumulation rate including instantaneous sedimentation events (turbidite deposits); $0.83 \mathrm{~cm} / \mathrm{yr}$ is the accumulation rate without instantaneous sedimentation events (Smith, 1997).

${ }^{2}$ Rate averaged over Kangerlussuaq Fjord (Syvitski et al., 1996).

rate from Kangerlussuaq Fjord (Syvitski et al., 1996). The biogenic, silica-rich sediments of the East Greenland fjords and continental shelves are sometimes deficient in enough carbonate material for radiocarbon dating at close intervals (Andrews et al., 1994, 1996, 1997; Jennings and Weiner, 1996; Syvitski et al., 1996; Smith, 1997). Radiocarbon dating of bulk sedimentary organic material in East Greenland produced erroneously old ages because of contamination by old carbon from ancient sedimentary rocks and coal deposits (Andrews et al., 1994).

The most recent radiocarbon-based estimates of SAR for East Greenland fjords (Table 2) are $0.83 \mathrm{~cm} / \mathrm{yr}$ for Kangerlussuaq Fjord, $0.12 \mathrm{~cm} / \mathrm{yr}$ for Miki Fjord, and from 0.18 to $0.13 \mathrm{~cm} / \mathrm{yr}$ for two sites in Nansen Fjord (Jennings and Weiner, 1996; Smith, 1997). The modern-day SAR estimates for Kangerlussuaq Fjord, based on shipboard observations and floc-camera data, range from $2.4 \mathrm{~cm} / \mathrm{yr}$ at the fjord head to $0.6 \mathrm{~cm} / \mathrm{yr}$ at the mouth of the fjord, with a basin average of $0.9 \mathrm{~cm} / \mathrm{yr}$ (Syvitski et al., 1996). In Kangerlussuaq Trough, the radiocarbon-based estimate of SAR is $0.006 \mathrm{~cm} / \mathrm{yr}$ (Andrews et al., 1996). In SW Iceland, the radiocarbon-based SAR is $0.002 \mathrm{~cm} / \mathrm{yr}$ (Hagen, 1995; Jennings et al., 2001).

\section{Use of ${ }^{210} \mathrm{~Pb}$ and ${ }^{137} \mathrm{Cs}$ Activity as Geochronological Tools}

The application of ${ }^{210} \mathrm{~Pb}$ as a dating tool for high-resolution records deposited over the past 150 years was first introduced by Goldberg (1963). Lead-210 is not an absolute clock; instead, it yields a relationship between depth and time from which sediment accumulation rates are derived (Crusius and Anderson, 1992). These rates can be verified by a second radiotracer, such as ${ }^{137} \mathrm{Cs},{ }^{241} \mathrm{Pu}$, or ${ }^{239+240} \mathrm{Pu}$ (Alexander et al., 1991; Appleby and Oldfield, 1992; Crusius and Anderson, 1992). Lead-210 enters lakes, estuaries, or marine environments primarily from two sources. The first is scavenging of unsupported (termed "excess") ${ }^{210} \mathrm{~Pb}$ derived from decay of gaseous ${ }^{222} \mathrm{Rn}$, the daughter of ${ }^{226} \mathrm{Ra}$, which diffuses out of soils to decay to ${ }^{210} \mathrm{~Pb}$ in the atmosphere, in rivers, and in the ocean. The second source is insitu decay of ${ }^{226} \mathrm{Ra}$ within deposited sediments (termed "supported" ${ }^{210} \mathrm{~Pb}$ ) (Oldfield, 1983). Supported ${ }^{210} \mathrm{~Pb}$ is the result of in-situ decay of ${ }^{222} \mathrm{Rn}$ within sediments and is considered to be in secular equilibrium with its parent, ${ }^{226} \mathrm{Ra}$
(Oldfield, 1983; Appleby and Oldfield, 1992). The excess ${ }^{210} \mathrm{~Pb}$ provides the data needed to calculate accumulation rates and age dating. Excess ${ }^{210} \mathrm{~Pb}$ is calculated by subtracting the amount of measured supported ${ }^{210} \mathrm{~Pb}$ from the total measured amount of ${ }^{210} \mathrm{~Pb}$ and is usually reported in disintegrations per minute/gram $(\mathrm{dpm} / \mathrm{g})$.

The use of ${ }^{210} \mathrm{~Pb}$ to calculate sediment accumulation rates from the amount of unsupported ${ }^{210} \mathrm{~Pb}$ is dependent upon the basic assumption that the initial excess ${ }^{210} \mathrm{~Pb}$ activity in sediment is constant, is not redistributed or remobilized by post-depositional processes, and decays exponentially with time in accordance with the radioactive decay law (Oldfield, 1983; Appleby, 1993). The source of excess ${ }^{210} \mathrm{~Pb}$ in marine sediments cannot always be attributed solely to atmospheric flux, because the atmospheric flux of excess ${ }^{210} \mathrm{~Pb}$ to marine environments decreases with distance from the lithogenic source of ${ }^{226} \mathrm{Ra}$. Other sources of excess ${ }^{210} \mathrm{~Pb}$ include riverine runoff, glacial, iceberg or sea-ice meltwater, and decay of ${ }^{226} \mathrm{Ra}$ within the water column. The decay of ${ }^{226} \mathrm{Ra}$ within the water column is especially important in the ocean because upwelled water has large amounts of excess ${ }^{210} \mathrm{~Pb}$. Bioturbation or resuspension of sediment (or both) after deposition may significantly alter the activity profile of excess ${ }^{210} \mathrm{~Pb}$ and produce incorrect sediment accumulation rates unless taken into account (Appleby and Oldfield, 1992). Determination of the surficial mixed layer, typically formed by bioturbation or current or wave action, is crucial to ${ }^{210} \mathrm{~Pb}$ chronology because the measured activity of excess ${ }^{210} \mathrm{~Pb}$ will be constant through the sediment mixed layer (Nittrouer, 1978). Deeper in the sediment column, intervals of constant ${ }^{210} \mathrm{~Pb}$ activity levels may be attributed to sediment gravity flows or current winnowing (Harden et al., 1992).

Cesium-137 is a particle-reactive impulse tracer derived from atmospheric nuclear weapons testing. It was first introduced into the environment in 1954, reaching a peak in input in 1963, and its input has declined with the shift to below-ground testing in subsequent decades. Cesium-137 on particles derived from land and freshwater environments is tightly bound, whereas the ${ }^{137} \mathrm{Cs}$ scavenged by marine particles is relatively exchangeable (Zucker et al., 1984; Olsen et al., 1989). Thus, a high activity level of ${ }^{137} \mathrm{Cs}$ in marine sediments typically indicates terrestrial sources. The integrity of the ${ }^{137} \mathrm{Cs}$ signal can be influenced by 
drainage basin storage of sediment, biological mixing, and sedimentary processes that redistribute seabed material. In glacierized drainage basins, ${ }^{137} \mathrm{Cs}$ may clarify whether the sediment is sourced directly from the glacier or is eroded and transported in the proglacial area by glaciofluvial processes (Hasholt and Walling, 1992).

\section{METHODOLOGY}

\section{Field Methods}

Sediment cores were collected from the fjords and inner continental shelves during joint oceanographic cruises of the Institute of Arctic and Alpine Research (INSTAAR) with the Bedford Institute of Oceanography in the fall of 1993 (cruise HU93030) and with the University of Troms $\varnothing$ in the fall of 1996 (cruise JM96) (Table 1). Box cores were recovered and at least two subcores $(10 \mathrm{~cm}$ diameter) were removed. One subcore from each of the 1993 box cores was split lengthwise, described, $\mathrm{x}$-radiographed, and sampled at INSTAAR in $2 \mathrm{~cm}$ intervals for ${ }^{210} \mathrm{~Pb}$ and sedimentological analysis. A second subcore was sampled on board for living foraminifera assemblage data. After core collection, all of the 1996 subcores were immediately frozen on board in an upright position because of extremely high water content. We do not think that freezing the cores had any major effect on core stratigraphy or the sedimentology data collected from the cores. The frozen cores were extruded from the core liner and sliced into $2 \mathrm{~cm}$ intervals on board, thus the cores were not described or x-radiographed. The outer rind of sediment from each 2 $\mathrm{cm}$ thick sample was removed because of possible sample disturbance. These samples were stored in the cold room and shipped to INSTAAR for sample preparation for ${ }^{210} \mathrm{~Pb}$ and sedimentological analysis.

\section{Laboratory Methods}

Radionuclide Measurement: Sediments from box cores in all three fjords and the continental shelves were analyzed for ${ }^{210} \mathrm{~Pb}$ activity (Table 1 ). The ${ }^{210} \mathrm{~Pb}$ samples from the 1993 box cores recovered in Kangerlussuaq Fjord (HU9323) and at the two continental shelf sites (HU93-19 and HU93-3) were shipped wet to Skidaway Institute of Oceanography, Georgia, for ${ }^{210} \mathrm{~Pb}$ measurement by alpha counting, using the technique described in Nittrouer (1978). Alpha counting determines ${ }^{210} \mathrm{~Pb}$ activity by measuring the activity of ${ }^{210} \mathrm{Po}$, the granddaughter of ${ }^{210} \mathrm{~Pb} .{ }^{210} \mathrm{~Pb}$ and ${ }^{210} \mathrm{Po}$ are typically in equilibrium in the seabed. Samples were dried and ground, spiked with ${ }^{208}$ Po tracer (for yield determination), and leached in nitric and hydrochloric acids. The leachate was separated from the solids by centrifugation, and the dissolved polonium isotopes in the liquid were plated spontaneously onto a silver planchet. Cesium137 , typically analyzed by gamma techniques, was not determined for samples by alpha counting.
The ${ }^{210} \mathrm{~Pb}$ samples from the 1996 box cores recovered in Miki Fjord (JM96-1212) and Nansen Fjord (JM96-1209, JM96-1210) were weighed wet, freeze-dried, and weighed dry, and $30 \mathrm{~g}$ of sediment was ground in a porcelain mortar and pestle. The ground sediment samples were shipped to Skidaway Institute of Oceanography for ${ }^{210} \mathrm{~Pb}$ measurement by gamma counting techniques. Ground samples for gamma analysis of ${ }^{210} \mathrm{~Pb}$ and ${ }^{137} \mathrm{Cs}$ were sealed in sample containers for 20 days to allow ingrowth of ${ }^{222} \mathrm{Rn}$. Total ${ }^{210} \mathrm{~Pb}$ was determined by measurement of the $46.5-\mathrm{KeV}$ ${ }^{210} \mathrm{~Pb}$ gamma peak (Cutshall et al., 1983). Supported ${ }^{210} \mathrm{~Pb}$ from the decay of ${ }^{226} \mathrm{Ra}$ within the seabed was determined by measurement of the granddaughters of ${ }^{226} \mathrm{Ra},{ }^{214} \mathrm{~Pb}$ (at 295 and $352-\mathrm{KeV}$ ) and ${ }^{214} \mathrm{Bi}$ (at $609-\mathrm{KeV}$ ). Unsupported ${ }^{210} \mathrm{~Pb}$ was determined by subtracting total ${ }^{210} \mathrm{~Pb}$ activity from supported ${ }^{210} \mathrm{~Pb}$ activity for each interval. Cesium137 activity in each interval was determined directly by gamma spectroscopic measurement of its $662-\mathrm{KeV}$ gamma peak (Kuehl et al., 1986), with a detection limit of $0.05 \mathrm{dpm} / \mathrm{g}$. Samples were corrected for self-adsorption using the technique of Cutshall et al. (1983). Accumulation rates were calculated by applying a constant initial concentration model to profiles of unsupported ${ }^{210} \mathrm{~Pb}$ activity versus cumulative mass with depth (Oldfield and Appleby, 1984). Cumulative errors associated with the ${ }^{210} \mathrm{~Pb}$ dating technique typically result in variation of $25 \%$ in calculated values (Kuehl et al., 1986; Alexander et al., 1991; Sommerfield and Nittrouer, 1999).

Sedimentology: Bulk density, total organic carbon (TOC), and magnetic susceptibility (MS) measurements were made on $10 \mathrm{~cm}^{3}$ size samples from both the 1993 and the 1996 box cores. The bulk density of both the wet and dry unit weights was calculated for each sample. The wet sample was weighed, divided by the sample volume, dried, and disaggregated through a $2000 \mu \mathrm{m}$ screen. A representative sample of the material smaller than $2000 \mu \mathrm{m}$ was weighed and then oven-dried. The ratio of the weight of the oven-dried sample to the air-dried sample was calculated and multiplied by the total weight of the air-dried sample smaller than $2000 \mu \mathrm{m}$ in order to obtain an oven-dried weight for the fraction smaller than $2000 \mu \mathrm{m}$. The ovendried weight for this fraction was added to the oven-dried weight of the sample larger than $2000 \mu \mathrm{m}$, and the result was divided by the volume of the total sample in order to calculate the dry unit weight.

Samples for organic carbon measurements were freeze dried, milled to smaller than $500 \mu \mathrm{m}$, and analyzed on a UIC Coulometrics CM5012 CO2 Coulometer. Magnetic susceptibility data for the 1993 box cores were collected on board on the whole core (volume MS) and converted to mass MS with the bulk density; mass MS data from the 1996 box cores were collected on discrete samples. Both MS measurements were made using a Barlington M.S. 2 Susceptibility Meter.

Porosity was calculated by water loss. Wet sediment was weighed, oven-dried, and reweighed to determine the volume of water in each sample. Porosity was determined 
after correcting for salt content, assuming a mineral density of $2.65 \mathrm{~g} / \mathrm{cc}$.

Bioturbation Evidence: Foraminifera samples were taken every $\mathrm{cm}$ from the 1993 box cores and were fixed in buffered Formalin on board. The samples were washed on a $63 \mu \mathrm{m}$ sieve. The greater than $63 \mu \mathrm{m}$ fraction was stained with Rose Bengal solution overnight to distinguish living from dead specimens. Samples were dried and sieved at $125 \mu \mathrm{m}$. A Soiltest, Inc. microsplitter was used to obtain a representative split of about 300 foraminifera from the fraction larger than $125 \mu \mathrm{m}$. Benthic foraminifera, both living (stained) and dead (unstained), were picked and identified using a stereomicroscope. The number of living foraminifera per milliliter is used as a bioturbation index, with a higher number of living foraminifera per $\mathrm{ml}$ indicating more bioturbation.

\section{RESULTS}

\section{Continental Shelves}

The two continental shelf sites are situated within shelf basins and are located approximately the same distance $(150 \mathrm{~km})$ from the coast. The core raised from the East Greenland shelf (HU93-19) consists of gray, silty clay with few, small dropstones, minor bioturbation at the core top, and sand-filled burrows scattered throughout the core. The ${ }^{210} \mathrm{~Pb}$ estimate of mass accumulation rate for HU93-19 is $0.09 \mathrm{~g} / \mathrm{cm}^{2} \cdot \mathrm{yr}$, with an equivalent sediment accumulation of $0.20 \mathrm{~cm} / \mathrm{yr}$ (Fig. 2). Across the Denmark Strait on the SW Iceland shelf, sediment recovered in core HU93-3 consists of tan-gray silty clay, with bioturbation evident throughout the core. But sediment structures are still visible in $\mathrm{x}$-radiograph, regardless of bioturbation. Core HU93-3 has a ${ }^{210} \mathrm{~Pb}$ estimate of mass accumulation of $0.14 \mathrm{~g}\left(\mathrm{~cm}^{2} \cdot \mathrm{yr}\right)$ and sediment accumulation of $0.22 \mathrm{~cm} / \mathrm{yr}$ (Fig. 2).

The East Greenland shelf sediments have a higher porosity (83\%) than the SW Iceland shelf sediments (75\%) (Fig. 3). The TOC and MS are similar on both continental shelves, varying from 1.3 to $1.85 \%$ and from 30 to $120 \times$ $10^{-7} \mathrm{~m}^{3} / \mathrm{kg}$, respectively (Fig. 3).

Bioturbation is occurring to approximately $5 \mathrm{~cm}$ depth in the continental shelf cores, as indicated by the presence of 2-10 live foraminifera/ml down to this depth (Fig. 4).

\section{East Greenland Fjords}

Sediment recovered in core HU93-23 from Kangerlussuaq Fjord consists of dark gray, silty clay with high amounts of dropstones throughout the core and little evidence for bioturbation. The ${ }^{210} \mathrm{~Pb}$ data from core HU9323 , located close to the fjord mouth, indicates that the mass accumulation in outer Kangerlussuaq Fjord is $0.43 \mathrm{~g} / \mathrm{cm}^{2} \cdot \mathrm{yr}$ and the sediment accumulation is $0.42 \mathrm{~cm} / \mathrm{yr}$ (Fig. 2). For Miki Fjord (JM96-1212), the ${ }^{210} \mathrm{~Pb}$ activity from the inner fjord, a few kilometers from the fjord head, produces a mass accumulation rate of $0.29 \mathrm{~g} / \mathrm{cm}^{2} \cdot \mathrm{yr}$ and a sediment accumulation rate of $0.37 \mathrm{~cm} / \mathrm{yr}$ (Fig. 2). The ${ }^{137} \mathrm{Cs}$ peak in Miki Fjord is found at $21 \mathrm{~cm}$ depth (Fig. 5). In Nansen Fjord, two box cores, one at mid-fjord and one at the fjord mouth, were measured for ${ }^{210} \mathrm{~Pb}$ activity. Core JM96-1209 is located approximately $15 \mathrm{~km}$ from the fjord head and has a mass accumulation rate of $1.01 \mathrm{~g} / \mathrm{cm}^{2} \cdot \mathrm{yr}$ and a sediment accumulation rate of $1.36 \mathrm{~cm} / \mathrm{yr}$ (Fig. 2). JM96-1210 is located at the fjord mouth, $30 \mathrm{~km}$ from the head, and produces a mass accumulation of $0.17 \mathrm{~g} / \mathrm{cm}^{2} \cdot \mathrm{yr}$ and a sediment accumulation of $0.22 \mathrm{~cm} / \mathrm{yr}$ (Fig. 2). The ${ }^{137} \mathrm{Cs}$ spike is at $5 \mathrm{~cm}$ depth in inner Nansen Fjord (JM96-1209) and at $2.5 \mathrm{~cm}$ depth in outer Nansen Fjord (JM96-1210) (Fig. 5).

The porosity differs in sediments from each of the East Greenland fjord box cores (Fig. 3). In Kangerlussuaq Fjord, the porosity is fairly constant downcore at $62 \%$. There are some intervals with slightly lower porosity. In Miki Fjord, the porosity steadily decreases downcore from $96 \%$ to almost 60\%. In Nansen Fjord, the inner fjord site (JM961209) has a lower porosity than the outer fjord (JM961210). The porosity at both sites increases downcore.

Kangerlussuaq Fjord has the lowest TOC of the three fjords, and Miki and Nansen Fjords have similar TOC (Fig. 3). All three fjords have lower TOC than was observed in cores recovered from the fjords in 1991 (Smith and Andrews, 2000). MS in Kangerlussuaq Fjord is less than $30 \times 10^{-7} \mathrm{~m}^{3} / \mathrm{kg}$. The MS in Miki Fjord is highest $\left(70 \times 10^{-7} \mathrm{~m}^{3} / \mathrm{kg}\right)$ at the core top, and steadily decreases downcore to approximately $10 \times 10^{-7} \mathrm{~m}^{3} / \mathrm{kg}$. The MS in Nansen Fjord is approximately $50 \times 10^{-7} \mathrm{~m}^{3} / \mathrm{kg}$. The differences in the TOC and MS values in the three fjords are attributed to the physiographic differences of the three fjords (Smith and Andrews, 2000).

In Kangerlussuaq Fjord, bioturbation is evident to approximately $5 \mathrm{~cm}$ depth, as indicated by the approximately 2-10 foraminifera/ml living to this depth (Fig. 4).

\section{DISCUSSION}

Sediment and mass accumulation rates based on ${ }^{210} \mathrm{~Pb}$ data are, as expected, higher in the East Greenland fjords than on the East Greenland continental margin (Andrews and Syvitski, 1994). Hence, the fjords are acting as traps for sediment, as is typical for fjords in interglacial periods (Syvitski et al., 1987). The continental shelf has a steadier rate of sediment accumulation than the fjords; thus, the ${ }^{210} \mathrm{~Pb}$ profiles for the shelf cores (Fig. 2) reflect this steadiness and are not an artifact of having used alpha versus gamma counting techniques.

\section{Comparison of Mass Accumulation Rates}

Continental Shelves: The two continental shelves have similar rates of sediment accumulation (Fig. 2), although the two sites are on opposite sides of the polar front and in 
Outer Kangerlussuaq Fjord

HU93-23

$210 \mathrm{~Pb}$ activity

(dpm/g)
Inner Miki

Fjord

JM96-1212

$210 \mathrm{~Pb}$ activity

(dpm/g)
Inner Nansen

Fjord

JM96-1209

$210 \mathrm{~Pb}$ activity

(dpm/g)
Outer Nansen

Fjord

JM96-1210

$210 \mathrm{~Pb}$ activity

(dpm/g)

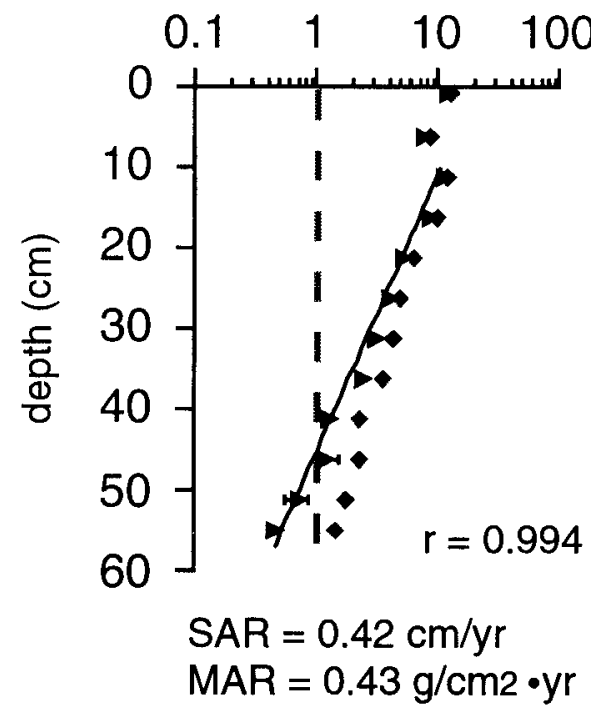

0.1110

0.1110
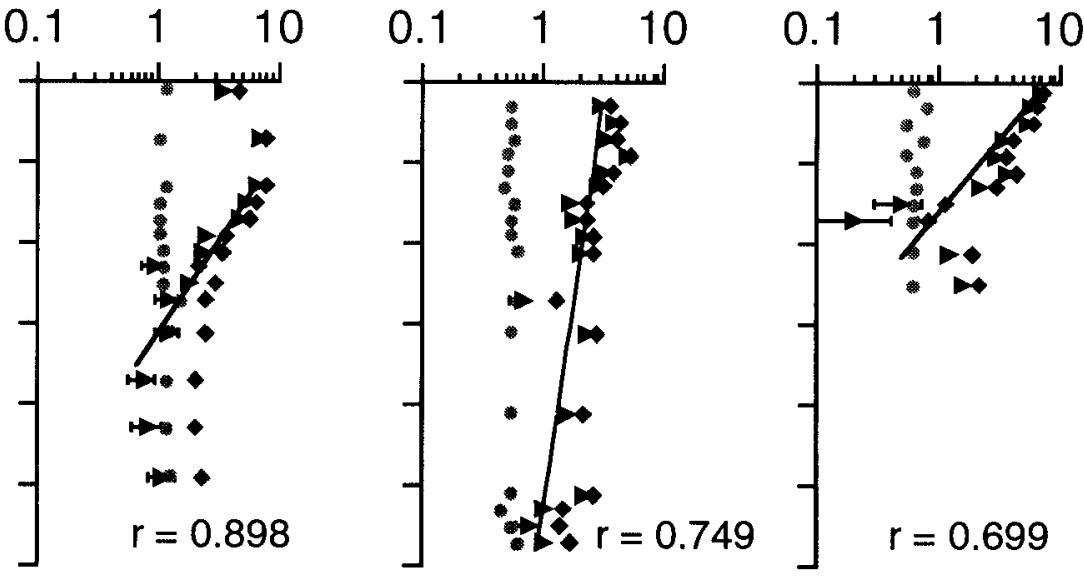

$\mathrm{SAR}=0.31 \mathrm{~cm} / \mathrm{yr}$

$\mathrm{SAR}=1.36 \mathrm{~cm} / \mathrm{yr}$

$\mathrm{SAR}=0.22 \mathrm{~cm} / \mathrm{yr}$

$\mathrm{MAR}=0.25 \mathrm{~g} / \mathrm{cm}^{2} \cdot \mathrm{yr}$

\section{East Greenland Shelf HU93-19}

210Pb activity (dpm/g)

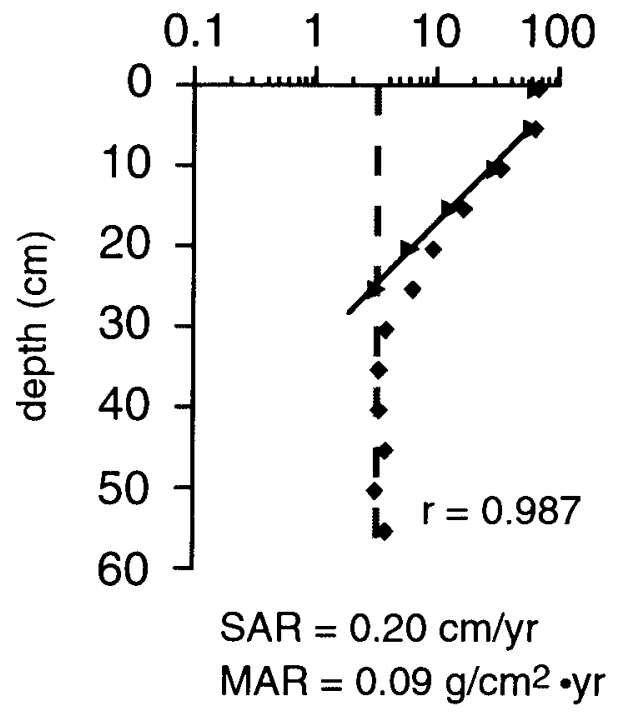

SW Iceland Shelf

HU93-3

$210 \mathrm{~Pb}$ activity

(dpm/g)

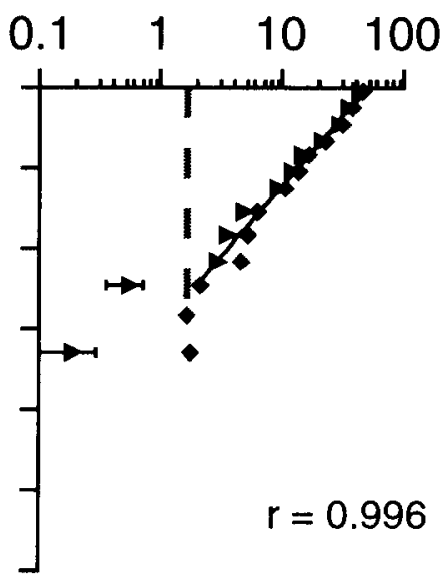

$\mathrm{SAR}=0.22 \mathrm{~cm} / \mathrm{yr}$

MAR $=0.14 \mathrm{~g} / \mathrm{cm}^{2} \cdot \mathrm{yr}$
- unsupported $210 \mathrm{~Pb}$

- total $210 \mathrm{~Pb}$

- supported $210 \mathrm{~Pb}$ (measured with gamma counting)

- - supported $210 \mathrm{~Pb}$ (estimated from zone of constant activity for HU93-19 and HU93-3; assumed for HU93-23)

FIG. $2 .{ }^{210} \mathrm{~Pb}$ profiles, calculated mass accumulation (MAR), and sediment accumulation (SAR) rates for box cores from Kangerlussuaq, Miki, and Nansen Fjords, the East Greenland continental shelf, and the SW Iceland continental shelf. Supported ${ }^{210} \mathrm{~Pb}$ values were estimated from the zone of constant activity in cores HU93-19 and HU93-3, and were assumed for core HU93-23. Error bars are shown when the error is greater than the size of the data point. 


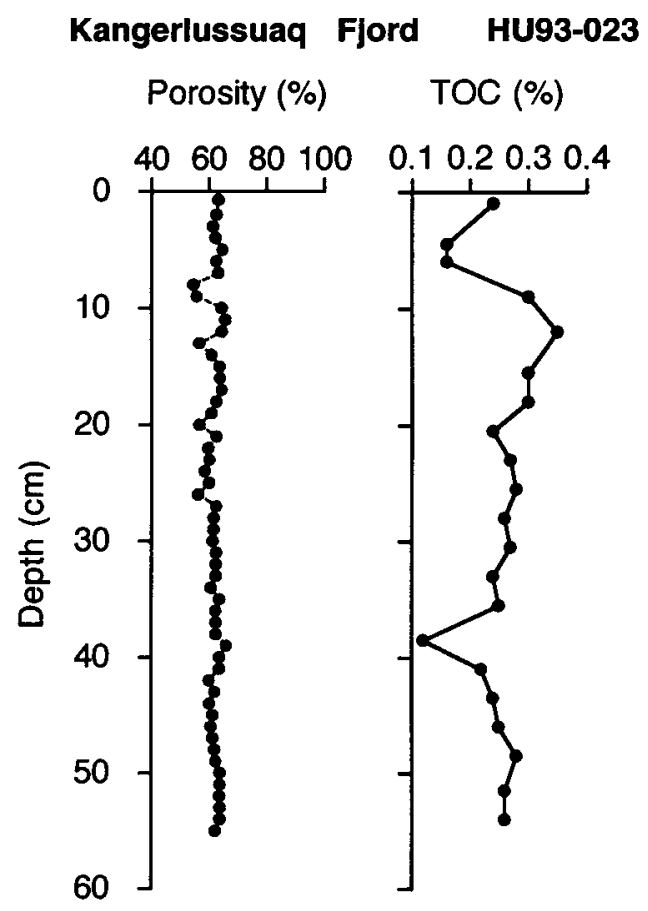

Nansen Fjord

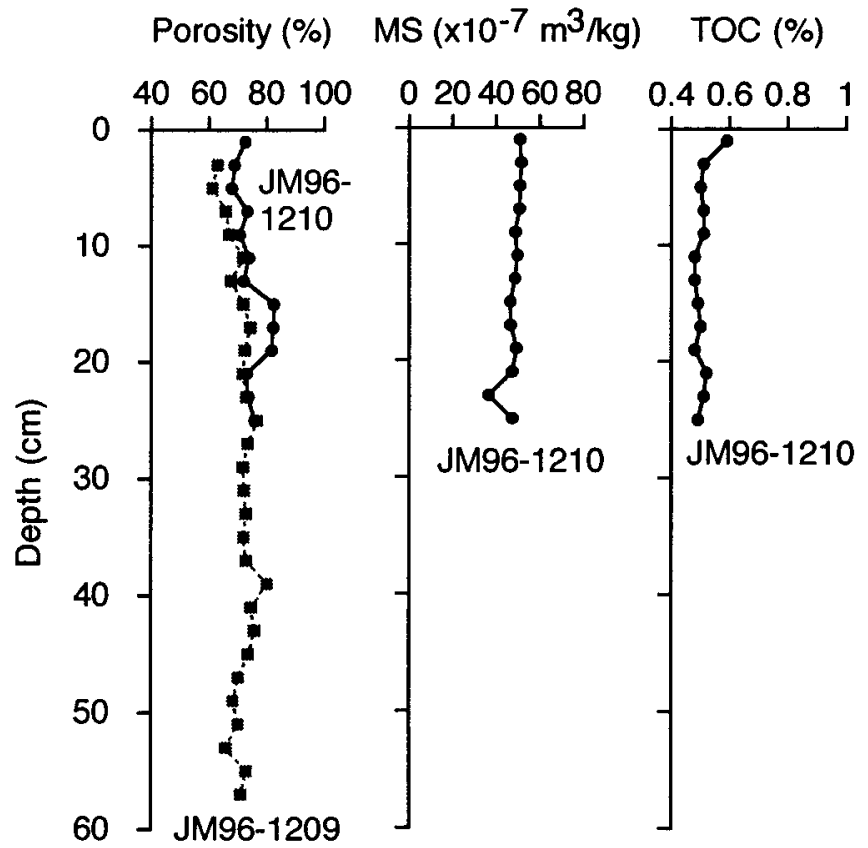

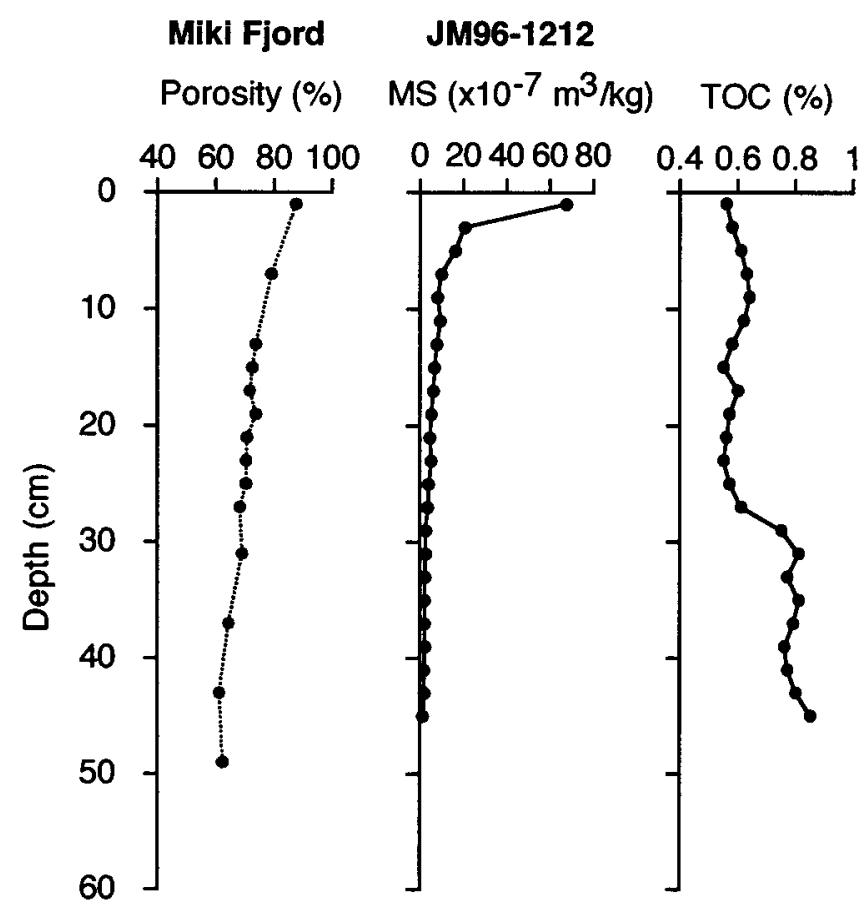

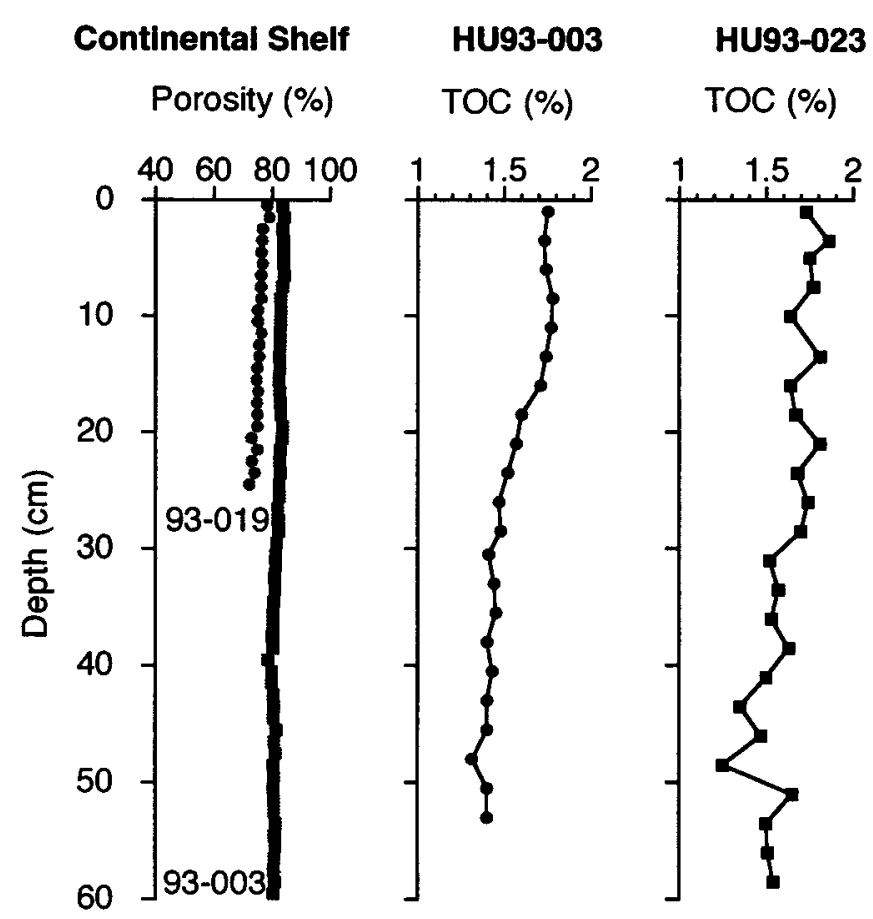

FIG. 3. Graphs of sedimentology data (porosity (\%), mass magnetic susceptibility $\left(\times 10^{-7} \mathrm{~m}^{3} / \mathrm{kg}\right)$, and TOC (\%) for the box cores used in this study.

different oceanographic regimes. Yet, the mass accumulation rate is higher on the Iceland margin. This difference in mass accumulation is attributed to the predominant sediment type. The East Greenland sediments are dominated by biogenic siliceous detritus, especially sponge spicules, which forms an open matrix on the seafloor, leading to higher porosity (Williams et al., 1995), whereas Iceland shelf sediments are rich in biogenic carbonate (Jennings et al., 2001), which forms a lower porosity matrix than the East Greenland sediments.
The sediment accumulation rates of the East Greenland and SW Iceland shelf sites fall within the range of rates estimated from ${ }^{210} \mathrm{~Pb}$ dating on the Antarctic Peninsula, 0.08 to $0.34 \mathrm{~cm} / \mathrm{yr}$ (Harden et al., 1992). However, they are greater than rates estimated from ${ }^{210} \mathrm{~Pb}$ dating on the continental shelf under the NE Water Polynya in northern Greenland, 0.13 to $0.6 \mathrm{~cm} / \mathrm{yr}$ (Roberts et al., 1997).

East Greenland Fjords: Differences in the ${ }^{210} \mathrm{~Pb}$ sediment and mass accumulation rates between the East Greenland fjords can be reconciled, given the differences in the 


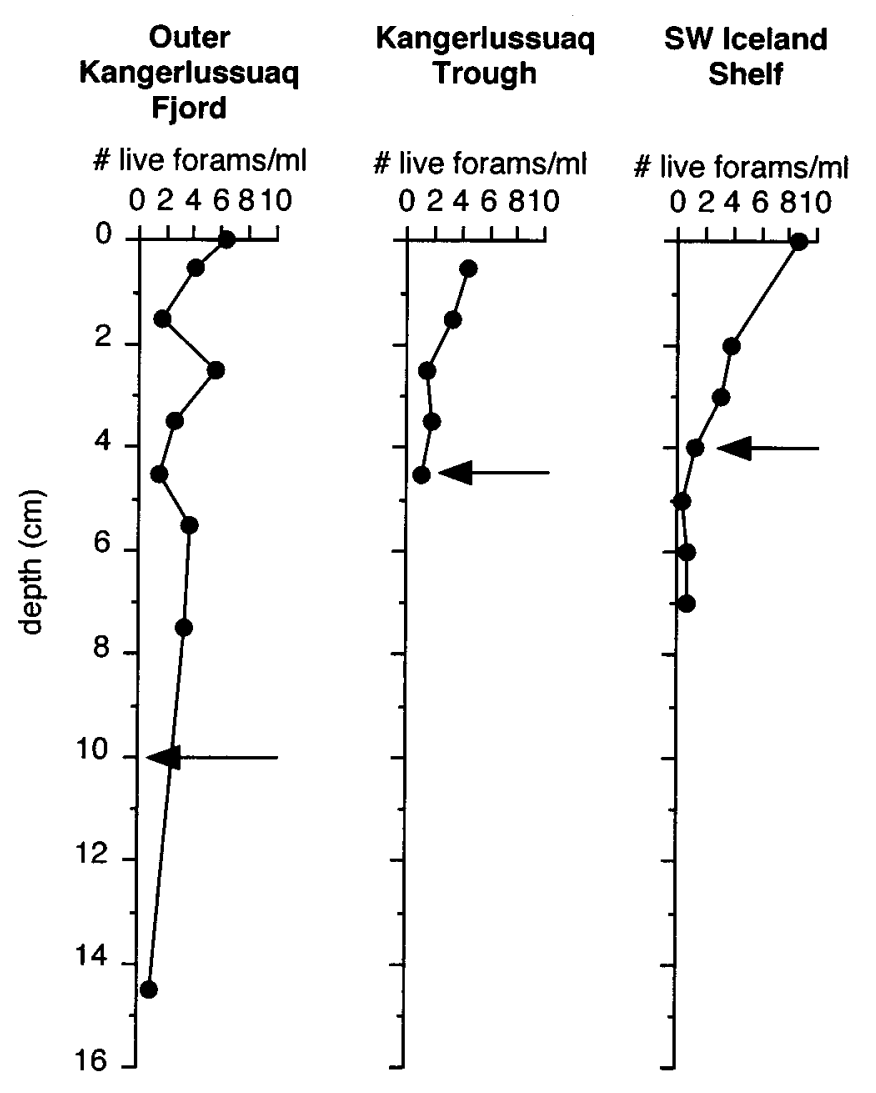

level of surface mixed layer from $210 \mathrm{~Pb}$ profiles

FIG. 4. Graphs of number of living foraminifera per $\mathrm{ml}$ from the ${ }^{210} \mathrm{~Pb}$ profiles for box cores from Kangerlussuaq Fjord and the continental shelves. Arrows indicate the depth of the surface mixed layer.

physiography, glaciology, and oceanography of the fjords. Figure 6 demonstrates the mass accumulation rate according to distance from the sediment source, using the ${ }^{210} \mathrm{~Pb}$ data presented in this paper, as well as mass accumulation rates based on suspended particulate matter (SPM) and observational measurements in Kangerlussuaq Fjord (Syvitski et al., 1996). Close to the source, Kangerlussuaq and Nansen Fjords have higher rates of mass accumulation than Miki Fjord. This difference is attributed to the dominant mode of glacial sediment delivery in the fjords. In Nansen and Kangerlussuaq Fjords, sediment is delivered via iceberg rafting, whereas in Miki Fjord, the sediment deposited in the fjord is glacial flour entrained in a river that drains a proglacial lake (Smith and Andrews, 2000). The river draining the proglacial lake carries a much lower amount of sediment than the iceberg and glacial meltwater plumes. Hallet et al. (1996) demonstrated that sediment yields from glaciated basins are higher than those from all other major, mostly river-dominated, basin types defined by Milliman and Syvitski (1992).

Kangerlussuaq Fjord maintains a higher mass accumulation rate than Nansen Fjord (Fig. 6), almost three times higher near the head of both fjords, and almost double at the mouth. The basin accumulation rate, the total mass of sediment between two dated boundaries normalized to the

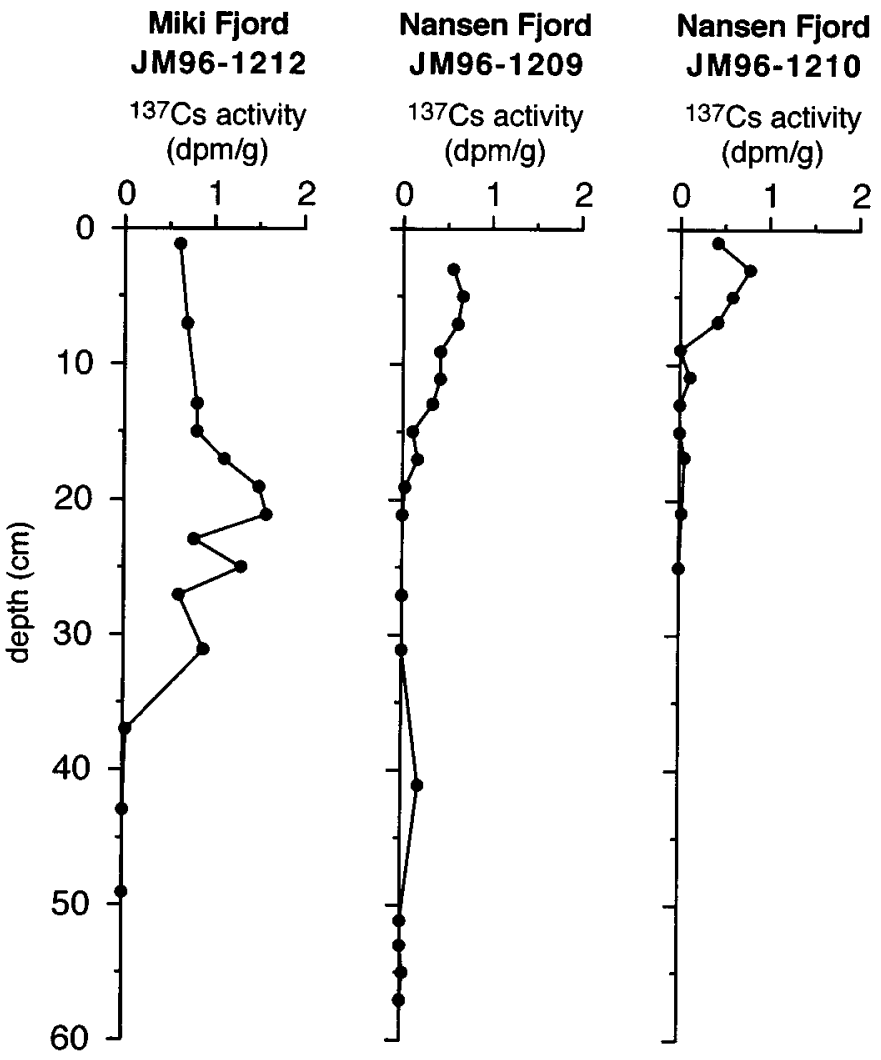

FIG. 5. Profiles of ${ }^{137} \mathrm{Cs}$ activity from Miki and Nansen Fjords. The error on the counting statistics for ${ }^{137} \mathrm{Cs}$ is less than the size of the data point.

basin area (Syvitski, 1993), provides a more meaningful comparison of Kangerlussuaq and Nansen Fjords. If we extrapolate the ${ }^{210} \mathrm{~Pb}$ rates back for $200 \mathrm{yrs}$, we obtain a thickness of the sediment column between two dated intervals, assuming the core top is $0 \mathrm{yrs}$. We use the actual seafloor accumulation area for the two fjords by subtracting the area of the fjord sidewalls. The area of Kangerlussuaq Fjord decreases by approximately half, from $375 \mathrm{~km}^{2}$ to $150 \mathrm{~km}^{2}$ (Syvitski et al., 1996), while that of Nansen Fjord decreases by approximately one-third, from $273 \mathrm{~km}^{2}$ to $100 \mathrm{~km}^{2}$. In the last 200 years, Kangerlussuaq Fjord has accumulated a basin average of $84 \mathrm{~cm}$, yielding a basin accumulation rate of $6300 \mathrm{~m}^{3} / \mathrm{yr}$, whereas Nansen Fjord has accumulated only $44 \mathrm{~cm}$, for a basin accumulation rate of $2200 \mathrm{~m}^{3} / \mathrm{yr}$. Hence, Kangerlussuaq Fjord is still accumulating sediment at higher rates than Nansen Fjord: the ratios are 2:1 for sediment accumulation, 2:1 for mass accumulation, and 3:1 for basin accumulation. These accumulation rate estimates for Kangerlussuaq and Nansen Fjords are similar to those predicted by Andrews et al. (1994) by simple mass balance equations using estimated iceberg calving rate and sediment volume entrained within the ice.

The higher basin and mass accumulation rates in Kangerlussuaq versus Nansen Fjord may be attributed to differences in the tidewater glacier regimes of the two fjords. Kangerlussuaq Gletscher calves about $15 \mathrm{~km}^{3}$ of ice/year, whereas Christian IV Gletscher calves only about 


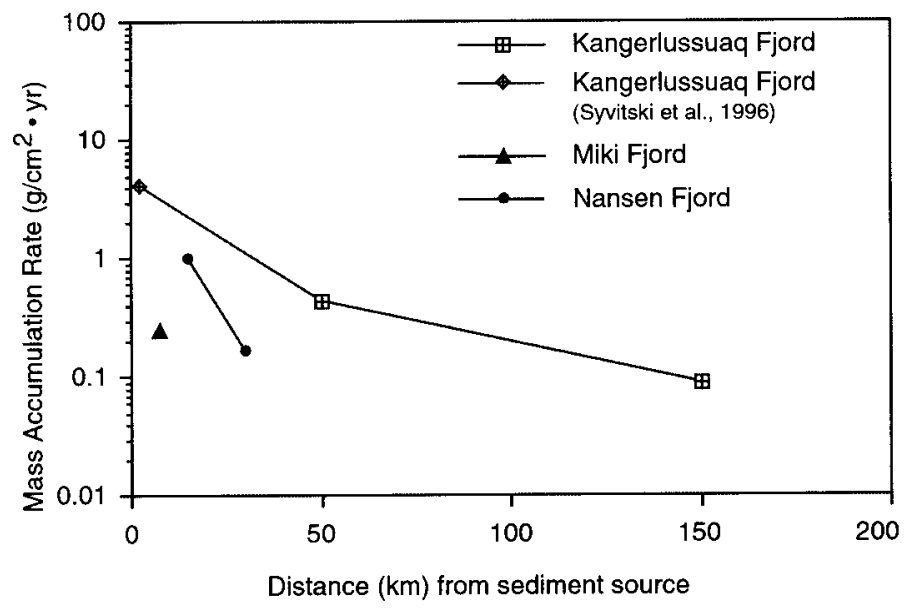

FIG. 6. Sedimentation rate versus distance from sediment source for the three East Greenland fjords. Note use of two different methods for estimating sedimentation rates in Kangerlussuaq Fjord, modern (Syvitski et al., 1996) versus ${ }^{210} \mathrm{~Pb}$ (this study).

$2 \mathrm{~km}^{3}$ of ice/year (Andrews et al., 1994). We expect that Kangerlussuaq Fjord would accumulate sediment at higher rates because the larger calving rate provides a larger sediment source, assuming that the amount of sediment entrained in the icebergs is similar for the two fjords (Andrews et al., 1994). A sikkusaq at the head of Kangerlussuaq Fjord traps calved icebergs for up to two years, and much of the subglacial debris is thought to be deposited during this period (Syvitski et al., 1996). However, not enough of the sediment is trapped to lower the accumulation rate to that of Nansen Fjord. An additional reason for the higher mass and basin accumulation in Kangerlussuaq Fjord may be the contribution of sediment from sidearm fjords. The total area of sidearm fjords in Kangerlussuaq Fjord equals that of Nansen Fjord. No data are available on the amount of sediment in these sidearm fjords, but satellite images indicate iceberg calving occurs there (Andrews et al., 1997), and seismic reflection data indicate the presence of turbidite channels at the mouth of Watkins Fjord (Syvitski et al., 1996).

The accumulation rates in these three East Greenland fjords are lower than those in Alaskan glaciomarine settings, such as $0.2-0.3 \mathrm{~cm} /$ day in Icy Bay from ${ }^{234} \mathrm{Th}$ data (Jaeger and Nittrouer, 1999) and 16-82 cm/yr in Muir Inlet based on ${ }^{210} \mathrm{~Pb}$ dating (Cowan, et al., 1999). However, they are higher than radiocarbon-based accumulation rates of $0.1-0.3 \mathrm{~cm} / 1000 \mathrm{yrs}$ in Scoresby Sund, East Greenland, just to the north of this region (Dowdeswell et al., 1994).

\section{Sedimentological Processes and Sediment Sources}

One assumption of the ${ }^{210} \mathrm{~Pb}$ geochronology is that the initial unsupported ${ }^{210} \mathrm{~Pb}$ activity decays exponentially with time and is not redistributed or remobilized by postdepositional processes (Oldfield, 1983; Appleby, 1993). Hence, it is important to evaluate the depth of the surface mixed layer for its potential influence on mixing excess ${ }^{210} \mathrm{~Pb}$. Additionally, sedimentology data, coupled with ${ }^{210} \mathrm{~Pb}$
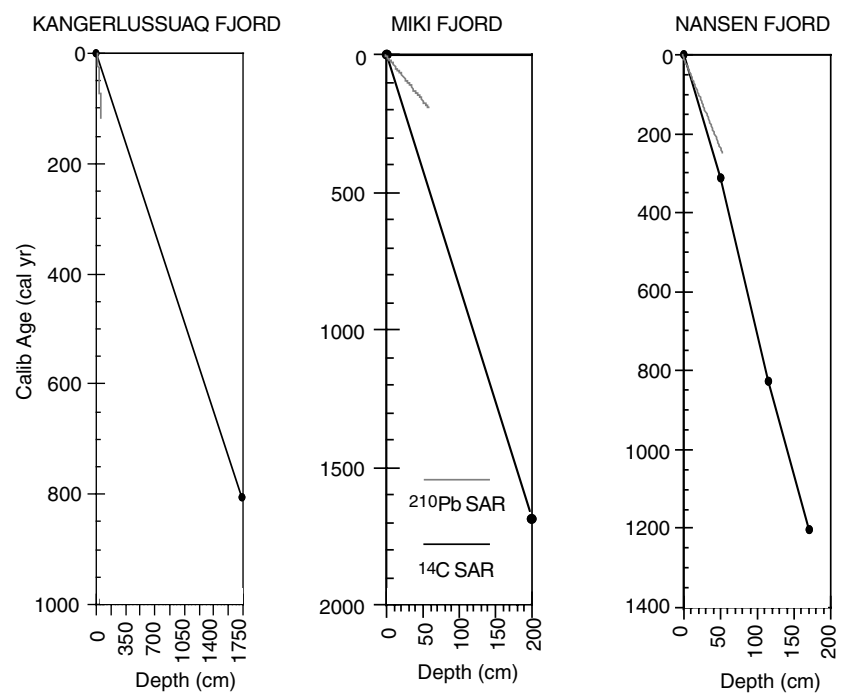

HU93-028 LCF:

${ }^{14} \mathrm{C} \mathrm{SAR}=2.15 \pm 0.24 \mathrm{~cm} / \mathrm{cal} \mathrm{yr}$

${ }^{14} \mathrm{C}$ SAR $=0.83 \pm 0.10 \mathrm{~cm} / \mathrm{cal}$ yr HU93-023 BC:

$210 \mathrm{~Pb}$ SAR $=0.42 \mathrm{~cm} / \mathrm{yr}$

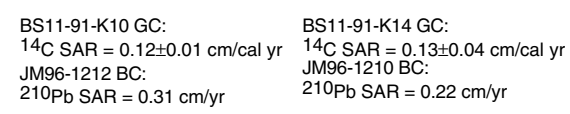

FIG. 7. Age versus depth plots based on ${ }^{210} \mathrm{~Pb}$ and ${ }^{14} \mathrm{C}$ data for the three East Greenland fjords. The ${ }^{210} \mathrm{~Pb}$ (dotted line) is higher than the ${ }^{14} \mathrm{C}$ estimate (solid line) in Miki and Nansen Fjords, but not in Kangerlussuaq Fjord.

profiles, may discern changes in sedimentary processes that might be altering the unsupported ${ }^{210} \mathrm{~Pb}$ (Smith and Ellis, 1982; Cowan et al., 1999), and the distribution of ${ }^{137} \mathrm{Cs}$ in the seabed can reflect the major sediment sources.

On both the East Greenland and SW Iceland margins, the ${ }^{210} \mathrm{~Pb}$ profiles show constant activity in the upper $5 \mathrm{~cm}$, and the ${ }^{210} \mathrm{~Pb}$ begins to decay exponentially only below $5 \mathrm{~cm}$. The homogenous intervals at the tops of each core can be attributed to bioturbation effects, as demonstrated by the number of live foraminifera/ml in these sediments (Fig. 4). Below the surface mixed layer, the ${ }^{210} \mathrm{~Pb}$ activity levels decay exponentially, as expected, indicating that there is no change in marine hemipelagic sedimentation through time.

Total organic carbon values are similar, and increasing upcore, on both sides of the Denmark Strait (Fig. 3), indicating that biogenic productivity is similar, although its source is different (siliceous versus carbonate) on each shelf. On the Iceland Shelf, there is a definite shift to higher TOC at approximately $20 \mathrm{~cm}$ that corresponds to a cold, lower-salinity interval (Jennings et al., 2001). During this time when these sediments were deposited, the flux of terrestrially derived carbon increased as a combination of climatic factors and human impacts increased soil erosion in Iceland (Jennings et al., 2001).

The similarity in the surface mixed layer depths estimated from alpha counting and from the depth of living foraminifera (Figs. 2 and 4) suggests that we are able to estimate the surface mixed depth from the cores without data on living foraminifera. In Kangerlussuaq Fjord, the upper $10 \mathrm{~cm}$ is homogenized, most likely by bioturbation, and the foraminifera are living to approximately that same 
depth (Fig. 4). Hence, both sites within Nansen Fjord appear to have a surface mixed layer down to $12 \mathrm{~cm}$, and Miki Fjord has a surface mixed layer down to $13 \mathrm{~cm}$.

The dominant depositional processes in these fjords over the last $2000{ }^{14} \mathrm{C}$ years are rainout of iceberg-rafted debris and sediment gravity flows (Smith and Andrews, 2000). Sediment rainout of iceberg rafting is the primary mode of deposition in all three fjords, with secondary depositional processes by sediment gravity flows (Smith and Andrews, 2000). The ${ }^{210} \mathrm{~Pb}$ profile in Kangerlussuaq Fjord does not indicate any gravity-flow deposits below the surface mixed layer, although approximately half of a previously collected $17 \mathrm{~m}$ piston core spanning the last 1600 calendar years at the site of box core HU93-23 was deposited by turbidity currents (Syvitski et al., 1996; Smith and Andrews, 2000). There is little evidence for sediment gravity flows in Miki Fjord, as the ${ }^{210} \mathrm{~Pb}$ profile decays linearly below the surface mixed layer. In contrast, sediment gravity flows rework and redistribute sediment in Nansen Fjord, as indicated by the smoothed intervals of ${ }^{210} \mathrm{~Pb}$ activity below the surface mixed layer from both cores in this fjord (Fig. 2). Sedimentological analysis of longer gravity cores recovered from Miki and Nansen Fjords also supports the respective absence and presence of turbidites (Jennings and Weiner, 1996; Smith and Andrews, 2000).

Major sediment sources can be discerned from the ${ }^{137} \mathrm{Cs}$ activity levels for Miki and Nansen Fjords. Miki Fjord has a ${ }^{137} \mathrm{Cs}$ activity level higher by a factor of two than that of Nansen Fjord (Fig. 5). The high activity level indicates that the source is riverine or lacustrine, as we would expect, given the glaciofluvial sediment supply emanating from the Sødalan Gletscher (as opposed to subglacial sediments or sediment near the ice margin). Hasholt and Walling (1992) demonstrated that proglacial sediment is higher in ${ }^{137} \mathrm{Cs}$ activity than sediment closer to the glacier because the proglacial sediments were exposed to the ${ }^{137} \mathrm{Cs}$, whereas sediment near the glacier was protected from ${ }^{137} \mathrm{Cs}$ by the glacier ice. The ${ }^{137} \mathrm{Cs}$ peak in Miki Fjord is located where it is predicted, given the accumulation rate and the thickness of the surface mixed layer. The occurrence of the ${ }^{137} \mathrm{Cs}$ spike at the correct depth within the sediment column suggests rapid transfer of the atmospheric signal on particles to the seabed of the fjord. Within Nansen Fjord, the peak is too shallow and the activity is low, suggesting that the signal is from mixed sources and incorporates a significant lag time between the 1963 atmospheric peak input and deposition on the seafloor in the fjord. The intricacies of ${ }^{137} \mathrm{Cs}$ exchange from glacier ice to the seafloor fjord are not well known, but it can be concluded that riverine or lacustrine input of ${ }^{137} \mathrm{Cs}$ to the marine environment is much more direct than input from a glacier source.

\section{Use of ${ }^{210} \mathrm{~Pb}$ Accumulation Rates for the Holocene}

Because of the short half-life of ${ }^{210} \mathrm{~Pb}$, this dating technique is applicable to only the last 150 years of sediment accumulation. For longer time scales, radiocarbon dating is reliable back to approximately 40000 years. Many studies have used both radiocarbon and ${ }^{210} \mathrm{~Pb}$ dating as a way to validate the estimated accumulation rates (Harden et al., 1992; Elverhøi et al., 1995). In some environments, there is a lack of sufficient material for radiocarbon dating, and researchers must use ${ }^{210} \mathrm{~Pb}$ dating to estimate accumulation rates over a longer time scale. But, unlike radiocarbon ages, which can be calibrated to calendar years, ${ }^{210} \mathrm{~Pb}$ profiles provide data on accumulation rates. Harden et al. (1992) found that ${ }^{210} \mathrm{~Pb}$ dating of high-latitude sediments in Antarctica is insufficient, and relied instead upon radiocarbon chronologies. In other high-latitude environments, such as SE Alaska, accumulation rates in the fjords are too high for either radiocarbon dating or ${ }^{210} \mathrm{~Pb}$ dating, and thorium dating must be used (Jaeger and Nittrouer, 1999).

There is an obvious discrepancy between the different accumulation estimates for the East Greenland fjords and continental shelves (Table 2, Fig. 7). In Kangerlussuaq Fjord, the modern accumulation rate is highest, with radiocarbon data yielding intermediate rates, and the ${ }^{210} \mathrm{~Pb}$ rate estimating the lowest accumulation. In Miki and Nansen Fjords and the two continental shelf sites, the radiocarbon data rate is lower and the ${ }^{210} \mathrm{~Pb}$ data rate is higher. Figure 7 shows the accumulation up to 2000 years, as estimated from ${ }^{210} \mathrm{~Pb}$ data, compared to radiocarbon data estimates for the East Greenland fjords. This discrepancy in accumulation rate estimates has been described by Sadler (1981:572) as "a consistent trend of falling mean sediment accumulation rates with increasing time span." Accumulation rates determined on shorter time scales are not good indicators of accumulation rates on longer time scales because sedimentary sections tend to incorporate more and longer hiatuses or erosional events with the longer time scale (Sadler, 1981). However, Sadler (1981) considers time scales that are over $10^{6} \mathrm{yrs}$, whereas we are interested in time scales of $10-10^{3} \mathrm{yrs}$.

We find that accumulation rates can easily be calculated using different geochronological methods, but the choice of an accumulation rate is dependent upon the interval in which the investigator is most interested, as the two accumulation estimates do not overlap well. Hence, although we were able to determine accumulation rates in carbonate-poor environments using ${ }^{210} \mathrm{~Pb}$ geochronology, we would be hesitant to extrapolate the ${ }^{210} \mathrm{~Pb}$ accumulation rate back in time throughout the Holocene to determine chronologies on millennial time scales.

\section{CONCLUSION}

We used ${ }^{210} \mathrm{~Pb}$ dating to estimate sediment and mass accumulation rates in the fjords and continental shelf of the Kangerlussuaq region, East Greenland. We also measured ${ }^{210} \mathrm{~Pb}$ on the SW Iceland continental shelf, in order to compare mass accumulation rates in contrasting marine 
environments across the Denmark Strait. The ${ }^{210} \mathrm{~Pb}$ data allowed us to establish modern mass accumulation rates for high-latitude marine and glacial marine environments, as well as to discern sedimentological processes occurring over the last century and to evaluate the use of extrapolating ${ }^{210} \mathrm{~Pb}$ accumulation rates to the Holocene. Sediment accumulation rates are similar on the continental shelves across the Denmark Strait, although the mass accumulation rates differ because the different biogenic composition of the sediments influences the bulk density.

Hemipelagic marine sedimentation has been the dominant depositional process on the continental shelves over the last 200 years, and both shelves experienced an increase in total organic carbon. On SW Iceland, the carbon increase is attributed to increased erosion from terrestrial carbon, whereas no direct anthropogenic forcing is known on the East Greenland margin.

Mass accumulation rates are higher in the fjords than on the continental shelves. The fjords have been acting as sediment traps over the last 200 years, and probably through much of the Holocene. Iceberg sediment rainout and sediment gravity flows have been the dominant depositional processes in the East Greenland fjords over the last 200 years. Within the three East Greenland fjords, the differences in mass accumulation rates is attributed to differences in sediment source, fluvial versus glacial marine (dominated by iceberg rafting). The differences between the Kangerlussuaq and Nansen Fjords are attributed to the amount of supplied sediment in calved icebergs and physiological differences in basin size.

\section{ACKNOWLEDGEMENTS}

We wish to thank the scientists and crew of the CSS Hudson and the RV Jan Mayen for core collection. Ship time on the CSS Hudson was supported by the Geological Survey of Canada and the Bedford Institute of Oceanography as part of the CANAM-PONAM project, and time on the RV Jan Mayen was provided by Dr. M. Hald, University of Troms $\varnothing$. Thanks to R. Kihl and N. Weiner for preparation of radiocarbon samples; to W. Freeman for sedimentological analyses of the JM96 samples; to W. Cunningham for TOC measurements on the HU93 cores; to J. Hardardóttir and $\mathrm{M}$. Berlin for help with the preparation of ${ }^{210} \mathrm{~Pb}$ samples; and to A. Simoneau, T. Elfers, and D. DeMaster for assistance with ${ }^{210} \mathrm{~Pb}$ analyses. Many thanks to the reviewers for their helpful and informative comments. This research was supported by grants from the National Science Foundation, Office of Polar Programs (OPP9615935, OPP-9707161 and OPP-9224254) and by a NOAA Consortium grant (NA47GP0188).

\section{REFERENCES}

ALEXANDER, C.R., DeMASTER, D.J., and NITTROUER, C.A. 1991. Sediment accumulation in a modern epicontinental-shelf setting: The Yellow Sea. Marine Geology 98:51-72.
ANDERSEN, C. 1998. Studier av klimavariabilitet i De Nordiske Hav og Danmarkstredet med hovedvekt pa de siste 2000 ar, basert pa diatomesammensetninger i marine kjerner. Cand. scient. oppgave i geologi, studieretning marin geologi, Universitetet i Bergen. $92 \mathrm{p}$.

ANDREWS, J.T., and SYVITSKI, J.P.M. 1994. Sediment fluxes along high latitude continental margins (NE Canada and E Greenland). In: Hay, W. Material fluxes on the surface of the Earth. Washington, D.C.: National Academy Press. 99-115.

ANDREWS, J.T., MILLIMAN, J.D., JENNINGS, A.E., RYNES, N., and DWYER, J. 1994. Sediment thicknesses and Holocene glacial marine sedimentation rates in three East Greenland fjords (ca. $68^{\circ} \mathrm{N}$ ). Journal of Geology 102:669-683.

ANDREWS, J.T., JENNINGS, A.E., COOPER, T., WILLIAMS, K.M., and MIENERT, J. 1996. Late Quaternary sedimentation along a fjord to shelf (trough) transect, East Greenland $\left(\right.$ c. $\left.68^{\circ} \mathrm{N}\right)$. In: Andrews, J.T., Austin, W.E.N., Bergsten, H., and Jennings, A.E., eds. Late Quaternary paleoceanography of the North Atlantic margins. London: Geological Society, Special Publication 111. 153-166.

ANDREWS, J.T., SMITH, L.M., PRESTON, R., COOPER, T., and JENNINGS, A.E. 1997. Holocene patterns of ice-rafted detritus (IRD) in cores from the East Greenland shelf. Journal of Quaternary Science 12:1-13.

APPLEBY, P.G. 1993. Foreword to the ${ }^{210} \mathrm{~Pb}$ dating anniversary series. Journal of Paleolimnology 9:155-160.

APPLEBY, P.G., and OLDFIELD, F. 1992. Application of Lead210 to sedimentation studies. In: Ivanovich, M., and Harmon, R.S., eds. U-series disequilibrium; applications to Earth, marine, and environmental studies. Oxford: Clarendon Press. 731 -778.

CLAPSADDLE, K. 1994. Silica extraction from the East Greenland shelf as a measure of productivity. 24th International Arctic Workshop, Arctic and Alpine Environments, Past and Present, Program with Abstracts, 1994. Boulder: Institute of Arctic and Alpine Research, University of Colorado at Boulder. $169 \mathrm{p}$.

COWAN, E.A., SERAMUR, K.C., CAI, J., and POWELL, R.D. 1999. Cyclic sedimentation produced by fluctuations in meltwater discharge, tides, and marine productivity in an Alaskan fjord. Sedimentology 46:1109-1126.

CRUSIUS, J., and ANDERSON, R.F. 1992. Inconsistencies in accumulation rates of Black Sea sediments inferred from records of laminae and ${ }^{210} \mathrm{~Pb}$. Paleoceanography 7(2):215-227.

CUTSHALL, N.H., LARSON, I.L., and OLSEN, C.R. 1983. Direct analysis of ${ }^{210} \mathrm{~Pb}$ in sediment samples: Self-absorption corrections. Nuclear Instruments and Methods 206:309-312.

DICKSON, R.R., MEINCKE, J., MALMBERG, S., and LEE, A. 1988. The "Great Salinity Anomaly" in the northern North Atlantic 1968-1982. Progress in Oceanography 20:103-151.

DOWDESWELL, J.A., UENZELMANN-NEBEN, G., WHITTINGTON, R.J., and MARIENFELD, P. 1994. The Late Quaternary sedimentary record in Scoresby Sund, East Greenland. Boreas 23:294-310.

DWYER, J.L. 1995. Mapping tide-water glacier dynamics in East Greenland using Landsat data. Journal of Glaciology 41(139):584-595.

ELVERHØI, A., SVENDSEN, J.I., SOLHEIM, A., ANDERSEN, E.S., MILLIMAN, J., MANGERUD, J., and HOOKE, R.LeB. 
1995. Late Quaternary sediment yield from the High Arctic Svalbard Area. The Journal of Geology 103:1-17.

GEIRSDÓTTIR, A., HARDARDÓTTIR, J., and ANDREWS, J.T. 2000. Late Quaternary terrestrial geology of Miki Fjord and nearby areas, East Greenland. Holocene 10(1):123-134.

GOLDBERG, E.D. 1963. Geochronology with Lead-210. In: Radioactive dating: Proceedings of the symposium on radioactive dating, International Atomic Energy Agency, Vienna. 121-131.

HAGEN, S. 1995. Watermass characteristics and climate in the Nordic Seas during the last 10,200 years. Troms $\varnothing$ : University of Troms $\varnothing .114 \mathrm{p}$.

HALLET, B., HUNTER, L., and BOGEN, J. 1996. Rates of erosion and sediment evacuation by glaciers: A review of field data and their implications. Global and Planetary Change 12:213-235.

HARDEN, S.L., DeMASTER, D.J., and NITTROUER, C.A. 1992. Developing sediment geochronologies for high-latitude continental shelf deposits: A radiochemical approach. Marine Geology 103:69-97.

HASHOLT, B., and WALLING, D.E. 1992. Use of caesium-137 to investigate sediment sources and sediment delivery in a small glacierized mountain drainage basin in East Greenland. Erosion, debris flows, and environments in mountain regions (Proceedings of the Chengda Symposium). IAHS publication 209:87-100.

JAEGER, J.M., and NITTROUER, C.A. 1999. Sediment deposition in an Alaskan fjord: Controls on the formation and preservation of sedimentary structures in Icy Bay. Journal of Sedimentary Research 69(5):1011-1026.

JENNINGS, A.E., and WEINER, N.J. 1996. Environmental changes in eastern Greenland during the last 1300 years: Evidence from foraminifera and lithofacies changes in Nansen Fjord, $68^{\circ} \mathrm{N}$. The Holocene 6(2):179-191.

JENNINGS, A.E., SYVITSKI, J.P.M., GRÖNVOLD, K., GERSON, L., GEIRSDÓTTIR, A., HARDARDÓTTIR, J., and ANDREWS, J.T. 2000. Chronology and paleoenvironments during the late Weichselian deglaciation of SW Iceland Shelf. Boreas 29(3): $167-183$.

JENNINGS, A.E., HAGEN, S., HARDARDÓTTIR, J., STEIN, R., OGILVIE, A.E.J., and JÓNSDÓTTIR, I. 2001. Oceanographic change and terrestrial human impact in a post AD 1400 sediment record from the southwest Iceland shelf. Climatic Change 48(1):83-100.

KUEHL, S.A., NITTROUER, C.A., and DeMASTER, D.J. 1986. Nature of sediment accumulation on the Amazon continental shelf. Continental Shelf Research 6:209-225.

MANLEY, W.F., and JENNINGS, A.E. 1996. Radiocarbon Date List VIII: Eastern Canadian Arctic, Labrador, Northern Quebec, East Greenland Shelf, Iceland Shelf, and Antarctica. Boulder: Institute of Arctic and Alpine Research, University of Colorado. Occasional Paper 50.

MILLIMAN, J.D., and SYVITSKI, J.P.M. 1992. Geomorphic/ tectonic control of sediment discharge to the ocean: The importance of small mountainous rivers. Journal of Geology 100:525-544.

NITTROUER, C.A. 1978. The process of detrital sediment accumulation in a continental shelf environment: An examination of the Washington Shelf. PhD thesis, University of Washington, $243 \mathrm{p}$.
OLDFIELD, F. 1983. Lead-210 and other isotopes. In: Creek, K.M., Tucholke, P., and Barton, C.E., eds. Geomagnetism of baked clays and recent sediments. Amsterdam: Elsevier. 57-62.

OLDFIELD, F., and APPLEBY, P.G. 1984. Empirical testing of ${ }^{210} \mathrm{~Pb}$ dating in models. In: Haworth, E.Y., and Lund, J.W.G., eds. Lake sediments and environmental history. Minneapolis: University of Minnesota Press. 93-124.

OLSEN, C.R., LARSEN, I.L., LOWRY, P.D., McLEAN, R.I., and DOMOTER, S. 1989. Radionuclide distributions and sorption behavior in the Susquehanna-Chesapeake Bay system. Maryland Power Plant and Environmental Review Division Report PPERR-12. Annapolis, Maryland: Department of Natural Resources. $106 \mathrm{p}$.

OVERPECK, J., HUGHEN, K., HARDY, D., BRADLEY, R., CASE, R., DOUGLAS, M., FINNEY, B., GAJEWSKI, K., JACOBY, G., JENNINGS, A., LAMOUREUX, S., LASCA, A., MACDONALD, G., MOORE, J., RETELLE, M., SMITH, S., WOLFE, A., and ZIELINSKI, G. 1997. Arctic environmental change of the last four centuries. Science 278:1251-1256.

REEH, N. 1985. Greenland ice-sheet mass balance and sea-level change. Glaciers, ice sheets, and sea level: Effect of a CO2 induced climatic change. Seattle: United States Department of Energy.

ROBERTS, K.A., COCHRAN, J.K., and BARNES, C. $1997 .{ }^{210} \mathrm{~Pb}$ and ${ }^{239,240} \mathrm{Pu}$ in the Northeast Water Polynya, Greenland: Particle dynamics and sediment mixing rates. Journal of Marine Systems 10:401-413.

SADLER, P.M. 1981. Sediment accumulation rates and the completion of the stratigraphic sections. Journal of Geology 89:569-584.

SMITH, J.N., and ELLIS, K.M. 1982. Transport mechanism for Pb210, Cs-137, and $\mathrm{Pu}$ fallout radionuclides through fluvialmarine systems. Geochimica et Cosmochimica Acta 46:941954.

SMITH, L.M. 1997. Late Quaternary glacial marine sedimentation in the Kangerlussuaq region, East Greenland, $68^{\circ}$ N. M.Sc. Thesis, Department of Geological Sciences, University of Colorado, Boulder. 190 p.

SMITH, L.M., and ANDREWS, J.T. 2000. Sediment characteristics in iceberg dominated fjords, Kangerlussuaq region, East Greenland. Sedimentary Geology 130:11-25.

SMITH, L.M., and LICHT, K.J. 2000. Radiocarbon DateList IX: Antarctica, Arctic Ocean, and the northern North Atlantic. INSTAAR Occasional Paper 54. 138 p.

SOMMERFIELD, C.K., and NITTROUER, C.A. 1999. Modern accumulation rates and a sediment budget for the Eel shelf: A flood-dominated depositional environment. Marine Geology 154(1-4):227-241.

STUIVER, M. 1993. A note on single yr calibration of the radiocarbon timescale, A.D. 1510-1954. Radiocarbon 35(1): $67-72$

STUIVER, M., and PEARSON, G.W. 1993. High-precision bidecadal calibration of the 14C timescale, A.D. 1950-500 B.C. and 2500-6000 B.C. Radiocarbon 35(1):1-23.

SYVITSKI, J.P.M. 1993. Glaciomarine environments in Canada: An overview. Canadian Journal of Earth Sciences 30(2): 354-371. 
SYVITSKI, J.P.M., BURRELL, D.C., and SKEI, J.M. 1987. Fjords: processes and products. New York: Springer Verlag. 379 p.

SYVITSKI, J.P.M., ANDREWS, J.T., and DOWDESWELL, J.A. 1996. Sediment deposition in an iceberg-dominated glaciomarine environment, East Greenland: Basin fill implications. Global and Planetary Change 12(1-4):251-270.
WILLIAMS, K.M., ANDREWS, J.T., WEINER, N.J., and MUDIE, P.J. 1995. Late Quaternary paleoceanography of the mid- to outer continental shelf, East Greenland. Arctic and Alpine Research 27(4):352-363.

ZUCKER, C.L., OLSEN, C.R., LARSEN, L.L., and CUTSHALL, N.H. 1984. Inventories and sorption-desorption trends in radiocesium and radiocobalt in James River Estuary sediments. Environmental Geology 6:171-182. 